\title{
THE USE OF PLASMA TORCHES IN BLAST FURNACE IRONMAKING*
}

\begin{abstract}
Development work on the use of plasma torches in blast furnace ironmaking was completed in the 1980s. The technology developers planned to reduce blast furnace coke consumption using electrical energy and large scale coal injection through the tuyeres. Since this time, Westinghouse Plasma Corporation has improved torch reliability with industrial experience in solid-waste-to-energy facilities, as well as metallurgical applications. As coke makes up one-third of the hot metal cost, savings efforts frequently seek to lower coke consumption by increasing process efficiency or replacing coke with cheaper fuels. Alter NRG and Hatch assessed the merits of using plasma torch technology to superheat the hot blast. Coke rate savings, electrical purchase requirements, and a financial analysis to implement the torches are presented.
\end{abstract}

Keywords: Blast furnace; Coke consumption; Plasma torch technology.

1 Chemical Engineer, Process Engineering, Iron \& Steel, at Hatch Ltd, Mississauga, ON, Canada; nishit.patel@hatch.ca

2 PhD, Materials Science and Engineering, Process Engineering, Iron \& Steel, at Hatch Ltd, Mississauga, ON, Canada; msukhram@hatch.ca

3 Metallurgical Engineer, Senior Director, Iron \& Steel, at Hatch Ltd, Mississauga, ON, Canada; icameron@hatch.ca

4 Chemical Engineer, Corporate Development Engineer at Alter NRG Corp, Calgary, AB, Canada; vsubramanyam@alternrg.ca

5 Chemical Engineer, Vice President at Alter NRG Corp, Calgary, AB, Canada; agorodetsky@alternrg.ca

6 Chemical Engineer, Process Engineer, Iron \& Steel, at Hatch Ltd, Mississauga, ON, Canada, mhuerta@hatch.ca 


\section{INTRODUCTION}

Extensive development work on the use of plasma torches in blast furnace ironmaking was completed in the 1980s. The technology developers planned to reduce blast furnace coke consumption using electrical energy and large scale coal injection through the tuyeres. Plasma torches were identified as an alternative technology to large scale oxygen enrichment which was considered too expensive at the time. Ultimately, plasma technologies were not implemented largely due to concerns with plasma torch reliability in the steel plant environment. Westinghouse Plasma Corporation has since improved torch reliability with industrial experience in solid-waste-to-energy facilities, as well as metallurgical applications. Since coke makes up one-third of the hot metal cost, savings efforts frequently seek to lower coke consumption by increasing process efficiency or replacing coke with cheaper fuels. With an increasing focus on lowering greenhouse gas emissions, plasma torches offer the opportunity to lower both coke rate and carbon dioxide emissions from the blast furnace by using a greater amount of electrical energy. Alter NRG and Hatch assessed the merits of using plasma torch technology to superheat the hot blast and reduce coke consumption in blast furnace operations. Coke rate savings, coal consumption, electrical purchase requirements for hot blast superheating, and a financial analysis to implement the torches are presented.

\section{HISTORY OF PLASMA TORCH USAGE IN BLAST FURNACE IRONMAKING}

\subsection{Early Developments}

Plasma torches are electric arc gas heaters that utilize a high temperature, ionized, and conductive gas to achieve direct heat transfer from the arc [1,2]. The technology was first developed in 1878 by W. Siemens when he used a direct current furnace for the bulk melting of metals. Early large-scale applications of plasma heaters were developed in Norway in the early 1900s to make nitrogen fertilizer from atmospheric air [2-4].

Westinghouse Plasma Corporation's (WPC) plasma technology was developed over a period of 30 years with an estimated $\$ 100$ million invested in research and development (R\&D). The WPC technology was initially developed in collaboration with NASA to produce clean high enthalpy gas flows to simulate reentry as part of the Apollo space program $[1,3,5]$. These early aerospace applications required plasma arcs at extremely high temperatures, and since testing for reentry did not require extended operation for many hours, long electrode life was not required for these testing systems. ${ }^{3}$ The proliferation of low power torches for cutting or welding applications led to smaller devices with more dependable operation and longer electrode life. ${ }^{3}$ Since the process energy from plasma is provided by direct heat transfer from an electric arc, gases of widely varying chemical composition can be heated. Plasma torches have the unique ability to increase the energy contained in a process gas by 2 to 10 times higher than that of conventional combustion equipment. The ability to use plasma torches to add large amounts of energy under controlled conditions led to their use across multiple industries [6]. 


\subsection{Metallurgical Applications}

Plasma technology has been applied in metallurgical processing to superheat process gases, direct smelting of ores and plant waste materials, as a combustion replacement, and for high temperature material testing [5,7]. The technology is especially appealing in ironmaking with its large energy consumption to smelt iron ores and produce molten iron and slag [1].

In the 1970s, the use of plasma technology to superheat the blast air to very high temperatures emerged as an opportunity to replace coke [1]. This led to a number of laboratory and pilot-scale tests that included injection of superheated gas into blast furnace tuyeres, and blast furnace wind superheating with plasma energy [7]. Pilot scale tests conducted at the Centre de Recherches Metallurgiques (CRM), Belgium used three (3) $20 \mathrm{~kW}$ torches to produce a heated reducing gas - natural gas reformed with $\mathrm{CO}_{2}$ at temperatures above $1,750^{\circ} \mathrm{C}$. Electrode life was over $400 \mathrm{~h}$, with $80 \%$ efficiency at a $2 \mathrm{MW}$ power level, and no electrical network problems were experienced [1]. These tests showed that the blast furnace process did not change if gases produced from reactions with coke and air were replicated with another gas of similar composition and temperature [1].

In 1980, Westinghouse Electric Corporation - in conjunction with Cockerill Steel, S.A, Belgium - designed and implemented a $3,500 \mathrm{~kW}$ single-phase plasma torch system for the injection of superheated air and natural gas into the tuyeres of a blast furnace. During single tuyere tests, a coke rate reduction was observed, and the study proved that plasma torches could indeed be used to superheat reducing gases for coinjection with hot blast air into the blast furnace. The torches provided an opportunity to use alternative fuels such as natural gas, coke oven gas or fuel oil without oxygen enrichment. The combination of high arc rotation speeds and large gas throughput velocities provided excellent heat transfer, thereby increasing overall process thermal efficiency [5].

In 1993, BHP used an electric resistance heater in conjunction with a $150 \mathrm{~kW}$ nitrogen plasma torch to heat the blast to $1,300^{\circ} \mathrm{C}$ in a tuyere simulator at its Newcastle Laboratory. BHP recommenced research to use pulverized coal injection (PCI) in 1996, with successful tests resulting in the tuyere injection of $\mathrm{PCl}$ at the Port Kembla blast furnaces in mid-2002 [8,9].

\subsection{Issues Using Plasma Torches in Commercial Scale Blast Furnace Plants}

In the 1980s, the returns on investment for plasma heating were similar to those for oxygen enrichment. While pilot and lab scale tests were successful, commercial success in the blast furnace was limited due to inadequate electrode life, torch performance issues in the steelworks' dirt-laden/wet environment, and the need for simple maintenance procedures to maintain electrode integrity $[6,7]$. The combined use of high levels of oxygen enrichment with pulverized coal injection and/or natural gas proliferated as this practice reduced coke consumption without the electrode life and efficiency concerns of plasma torches. Oxygen enrichment and fuel injection rapidly increased on a global basis.

Recognizing that additional coke savings could be achieved with plasma technologies, Westinghouse addressed the plasma torch performance issues that were identified in the early plant trials. In the intervening years, WPC torches were commercially deployed in over 34 different industrial applications in a wide variety of uses such as metals recycling, catalyst re-forming, heating of cupolas, and cleaning 
of industrial gases. From 1989 to 2008, the General Motors' Powertrain plant located in Defiance, Ohio, used a plasma fired cupola (PFC) to produce gray iron for engine blocks and automotive castings. The foundry successfully used six (6) MARC $11 \mathrm{H}$ plasma torches to increase the melt yield. Operating experience suggested that plasma technology is economically suitable for iron melting as the PFC provided a strong reducing atmosphere in the melting zone. No major changes to foundry operations were required to employ the PFC system. Key benefits for this system included reduced process gas velocities for the PFC compared to conventional cupolas due to lower coke usage [10].

\section{ALTER NRG AND WESTINGHOUSE PLASMA TORCHES}

Alter NRG acquired WPC in 2007 and has further developed the plasma torches to provide a clean source of heat to industrial processes. The plasma torch system along with its subsystems, including the arc heater, power supply components, cooling water system, gas system, and instrumentation and control system were improved [5]. The plasma unit was containerized to function better in the hostile blast furnace environment. The high voltage terminals were tightly sealed, and the container could be easily removed to provide access to the internal components for servicing and inspection. ${ }^{7}$ The improved plasma torch proved to be sufficiently rugged and durable to withstand the demands of industrial use [5].

The MARC 3A plasma torch was originally conceived as an experimental torch for pilot plants and R\&D applications. The design then became a standard for lower power applications between 80 and $300 \mathrm{~kW}$. The MARC $11 \mathrm{~L}$ and MARC $11 \mathrm{H}$ plasma torches were developed primarily for metal melting applications (Figure 1).

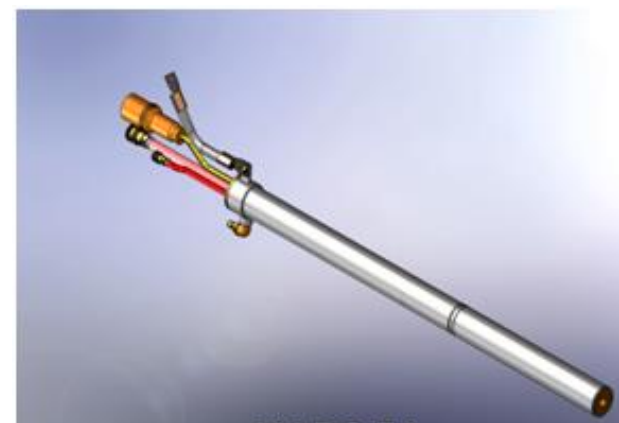

MARC 3A

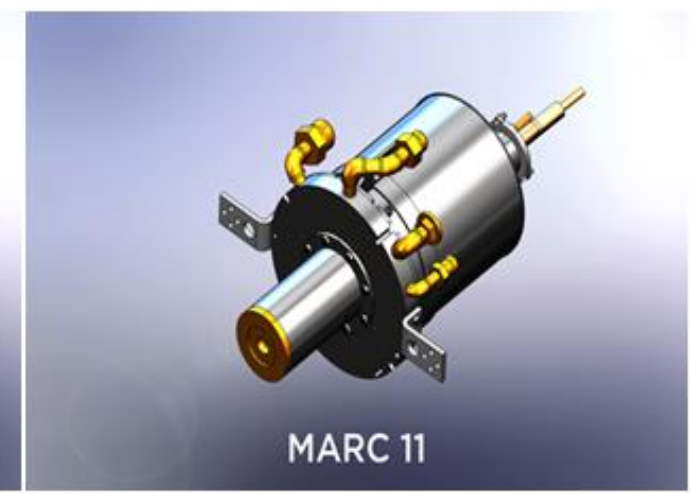

MARC 11

Figure 1. WPC Torches - MARC 3A and MARC 115

These torches have the ability to achieve temperatures beyond the limitations of combustion-based air heating. As such, the MARC 11 series of torches were specifically created for heating large quantities of blast air, and have a power rating up to $2.4 \mathrm{MW}$. The MARC 4.5 plasma torch fills the gap between the MARC 3 and MARC 11 series of torches; it is a robust, industrial torch capable of delivering over $500 \mathrm{~kW}$ of power to a process application. A summary of the WPC plasma torches is given in Table 1. 
Table 1. Summary of WPC plasma torches

\begin{tabular}{|l|c|c|c|c|}
\hline Type/ Features & MARC 3A & MARC 4.5 & $\begin{array}{c}\text { MARC } \\
\mathbf{1 1 L}\end{array}$ & $\begin{array}{c}\text { MARC } \\
\mathbf{1 1 H}\end{array}$ \\
\hline Power output & $80-300 \mathrm{~kW}$ & $280-530 \mathrm{~kW}$ & $\begin{array}{c}350-800 \\
\mathrm{~kW}\end{array}$ & $\begin{array}{c}860-2400 \\
\mathrm{~kW}\end{array}$ \\
\hline $\begin{array}{l}\text { Type of Control - } \\
\text { Independent control of } \\
\text { field coil and arc } \\
\text { current? }\end{array}$ & $\begin{array}{c}\text { No - Field coil in } \\
\text { series with arc } \\
\text { current }\end{array}$ & $\begin{array}{c}\text { Yes - power } \\
\text { controlled by } \\
\text { changing either } \\
\text { arc current, field } \\
\text { current or process } \\
\text { gas flow }\end{array}$ & $\begin{array}{c}\text { Yes - power is } \\
\text { controlled by changing } \\
\text { either the arc current, } \\
\text { field current or the } \\
\text { process gas flow }\end{array}$ \\
\hline $\begin{array}{l}\text { Design Characteristics/ } \\
\text { Challenges }\end{array}$ & $\begin{array}{c}\text { Flexible cylindrical } \\
\text { design; length of } \\
\text { torch can be } \\
\text { modified to suit } \\
\text { process needs. }\end{array}$ & $\begin{array}{c}\text { Flexible cylindrical } \\
\text { design; plasma } \\
\text { torch can be } \\
\text { inserted into hot } \\
\text { zone of a furnace. }\end{array}$ & $\begin{array}{c}\text { Fixed design; torches } \\
\text { typically used } \\
\text { externally; mounting } \\
\text { limitations. }\end{array}$ \\
\hline
\end{tabular}

\section{USE OF PLASMA TORCHES IN THE BLAST FURNACE}

In blast furnace ironmaking, the largest cost savings opportunity is to lower coke consumption by increasing process efficiency or replacing coke with less expensive replacement fuels. Using plasma torches to superheat the blast air to very high levels that are not possible with combustion processes offers a unique opportunity to further reduce the coke consumption to levels approaching the minimum coke rate. Hatch considered the impact of aggressive air superheating on the blast furnace process to understand potential benefits. Implementation would require additional engineering analysis to define the best plasma torch locations and verify the maximum temperature that the hot blast delivery system could achieve in existing facilities. The plasma technology could be phased in; this allows incremental benefits as the best superheating arrangement is developed.

To illustrate the impact of using plasma torches to superheat the blast air in a blast furnace operation, the cases listed in Table 2 were developed.

Table 2. Summary of coke replacement cases studied

\begin{tabular}{|c|c|}
\hline Case & Details \\
\hline 1 & Base case - typical blast furnace \\
\hline 2 & Increase blast temperature to $1,200^{\circ} \mathrm{C}$ \\
\hline 3 & Increase blast temperature to $1,400^{\circ} \mathrm{C}$ \\
\hline 4 & Increase blast temperature to $1,600^{\circ} \mathrm{C}$ \\
\hline 5 & Increase blast temperature to $1,800^{\circ} \mathrm{C}$ \\
\hline
\end{tabular}

\subsection{Case 1: Base case}

The base case representing a typical blast furnace was developed using Table 3. 
Table 3. Base case summary

\begin{tabular}{|l|c|c|}
\hline Parameter & Units & Value \\
\hline Sinter & $\mathrm{kg} / \mathrm{t} \mathrm{HM}$ & 404 \\
\hline Pellets & $\mathrm{kg} / \mathrm{t} \mathrm{HM}$ & 1,093 \\
\hline Coke & $\mathrm{kg} / \mathrm{t} \mathrm{HM}$ & 387 \\
\hline $\mathrm{PCl}$ & $\mathrm{kg} / \mathrm{t} \mathrm{HM}$ & 128 \\
\hline Fuel rate & $\mathrm{kg} / \mathrm{t} \mathrm{HM}$ & 502 \\
\hline Specific blast volume & $\mathrm{m}^{3}(\mathrm{~S} . \mathrm{T} . \mathrm{P}.) / \mathrm{t}$ & 990 \\
\hline Blast temperature & ${ }^{\circ} \mathrm{C}$ & 1,065 \\
\hline Flame temperature & ${ }^{\circ} \mathrm{C}$ & 2,220 \\
\hline $\mathrm{O}_{2}$ content in blast & $\%$ & 26 \\
\hline \multicolumn{2}{|c|}{${ }^{*}$ Fuel rate $=$ Coke rate $+(0.9 \times P C l$ rate $)$} \\
\hline \multicolumn{2}{|c|}{}
\end{tabular}

Subsequent cases were developed by superheating the blast air, while maintaining a top gas temperature between $120^{\circ} \mathrm{C}$ and $130^{\circ} \mathrm{C}$, a constant metallic feed, hot metal chemistry, and raceway adiabatic flame temperature (RAFT). Coke and $\mathrm{PCl}$ rates were adjusted to satisfy both furnace heat and reduction requirements.

\subsection{Cases 2 to 5: Using plasma torches to increase the blast temperature}

The blast temperature was increased from the base case of $1,065^{\circ} \mathrm{C}$ up to $1,800^{\circ} \mathrm{C}$ using plasma energy. The coke rate associated with the maximum blast air temperature of $1,800^{\circ} \mathrm{C}(178 \mathrm{~kg} / \mathrm{t} \mathrm{HM})$ approaches the minimum coke rate needed for iron carburization and ferrous burden support - a plasma superheated blast could enable the blast furnace to minimize coke close to theoretical minimum rates. At such temperatures, the burden distribution in the furnace would need to be adjusted to account for the lower coke rate. Further consideration and research would be required to understand the impact of gas flow within the furnace at very low coke rates. The major changes for all cases are presented in Figure 2 below.

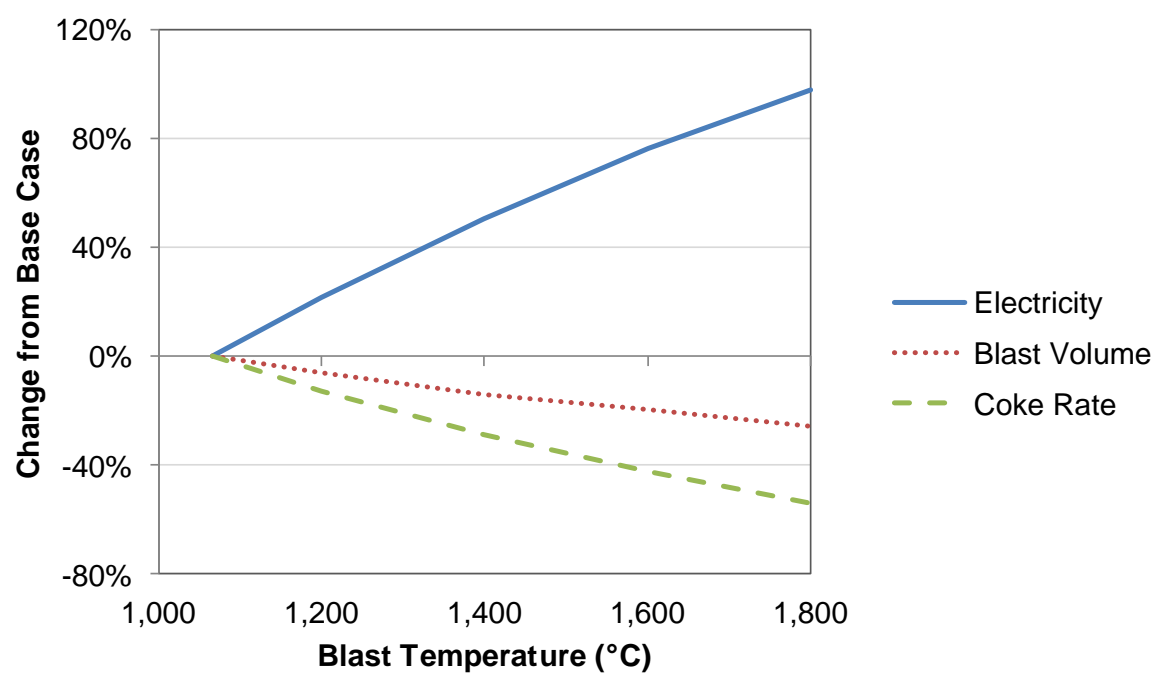

Figure 2. Impact of increasing blast temperature using plasma torches.

A summary of the different coke replacement strategies is provided in the Table 4 below: 
Table 4. Impact of increasing blast temperature as a coke replacement strategy

\begin{tabular}{|l|c|c|c|c|c|c|}
\hline Parameter & Units & $\begin{array}{c}\text { Case } \\
\mathbf{1}\end{array}$ & $\begin{array}{c}\text { Case } \\
\mathbf{2}\end{array}$ & $\begin{array}{c}\text { Case } \\
\mathbf{3}\end{array}$ & $\begin{array}{c}\text { Case } \\
\mathbf{4}\end{array}$ & $\begin{array}{c}\text { Case } \\
\mathbf{5}\end{array}$ \\
\hline Blast temperature & ${ }^{\circ} \mathrm{C}$ & 1,065 & 1,200 & 1,400 & 1,600 & 1,800 \\
\hline Coke & $\mathrm{kg} / \mathrm{t} \mathrm{HM}$ & 387 & 338 & 276 & 223 & 178 \\
\hline $\mathrm{PCl}$ & $\mathrm{kg} / \mathrm{t} \mathrm{HM}$ & 128 & 157 & 196 & 233 & 259 \\
\hline Fuel Rate* & $\mathrm{kg} / \mathrm{t} \mathrm{HM}$ & 502 & 480 & 452 & 433 & 411 \\
\hline Blast volume & $\mathrm{Nm}^{3} / \mathrm{t} \mathrm{HM}$ & 990 & 930 & 855 & 800 & 738 \\
\hline Blast oxygen & $\%$ & 26 & 26 & 26 & 26 & 26 \\
\hline Flame temperature & ${ }^{\circ} \mathrm{C}$ & 2,220 & 2,220 & 2,220 & 2,220 & 2,220 \\
\hline Top gas temperature & ${ }^{\circ} \mathrm{C}$ & 127 & 125 & 125 & 128 & 121 \\
\hline Electricity & $\mathrm{kWh} / \mathrm{t} \mathrm{HM}$ & 150 & 183 & 226 & 265 & 297 \\
\hline $\begin{array}{l}\text { Electrical demand for a } \\
6,000 \text { t/d BF }\end{array}$ & $\mathrm{MW}$ & 38 & 46 & 56 & 66 & 74 \\
\hline $\begin{array}{l}\text { Number of MARC } 11 \mathrm{H} \\
\text { units required at 2,400 } \mathrm{kW} \\
\text { each and 85\% efficiency }\end{array}$ & \multicolumn{7}{|l|}{} & 4 & 8 & 12 & 16 \\
\hline
\end{tabular}

Fuel usage between the various cases is compared in Figure 3 . The $\mathrm{PCl}$ rate increases with blast temperature to reduce the flame temperature back to the base case value of $2,220^{\circ} \mathrm{C}$. The blast oxygen enrichment is fixed for all cases presented.

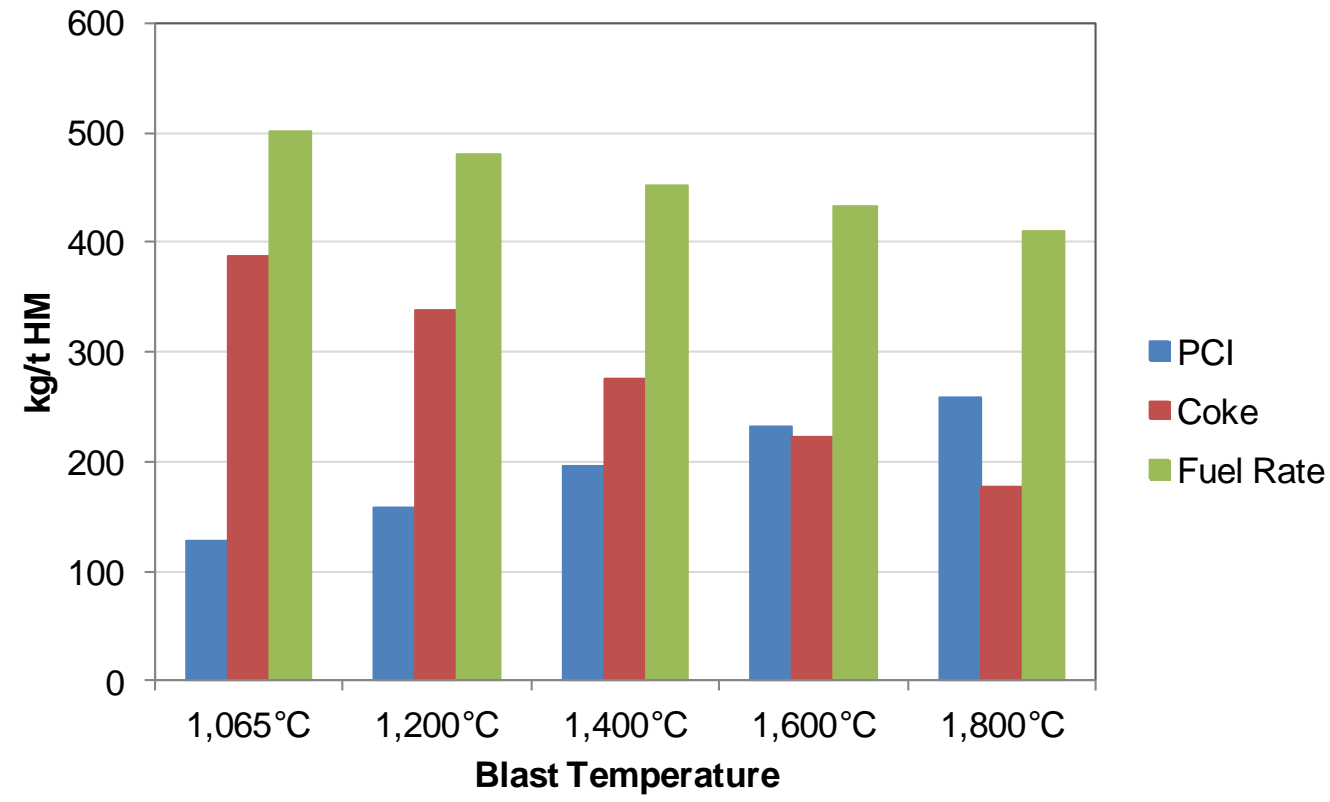

Figure 3. Fuel rate comparison across the cases.

To achieve the maximum temperature of $1800^{\circ} \mathrm{C}$ on a $6,000 \mathrm{t} / \mathrm{d}$ blast furnace, 16 Westinghouse MARC $11 \mathrm{H}$ units would be needed based on a torch thermal efficiency of $85 \% .{ }^{5}$ Torch requirements for the complete range of blast temperatures considered can be seen in Table 4.

\subsection{Considerations for installing plasma torches at the blast furnace}

In a blast furnace plant, potential locations for installation of the plasma torches for blast superheating include the hot blast main, bustle pipe and penstocks immediately 
above each tuyere, or combinations of these locations. The larger MARC 11 plasma torches ideally require a strong mounting point and good access for planned maintenance. Location of plasma torches in the hot blast main, mounted in a ring, could allow for initial hot blast heating with 3-6 torches between the stove discharge and the junction between the bustle pipe and hot blast main. Locating additional torches in the bustle pipe close to the entrance would be an additional opportunity to superheat the blast air. The plasma torches should be mounted symmetrically on either side of the bustle pipe entrance to ensure even heating of the blast air delivered to each tuyere. Potentially 4-5 torches could be installed on either side of the bustle pipe for a total of 8-10 torches. Combining both approaches, the potential to implement 12 torches is worth further engineering investigations.

Installing a smaller plasma torch at each tuyere was deemed too challenging due to the demanding environment and to reduce the number of torches employed. Regardless of the location chosen, appropriate protective measures must be taken to account for potential fire hazard issues and hot blast system integrity due to the high temperature gas flows involved. For instance, at higher blast temperatures, the refractory lining of the hot blast main, bustle pipe and penstocks would need to be replaced with higher temperature brick (more expensive), or a redesigned bustle pipe with cooling technology would need to be implemented to keep the refractory intact and from glazing over. This would increase the implementation cost and requires further engineering and development.

In addition to the power supply, air, and water systems for the plasma torches, the plant electrical infrastructure, such as the substation and transformer may require upgrades to handle the power load from the plasma torches. In many older plants redundant electrical distribution equipment may be available, reducing the investment costs.

\section{FINANCIAL ANALYSIS}

The cost of producing hot metal (HM) was calculated based on the assumed costs shown in Table 5 that reflect the early 2016 time period.

Table 5. Cost inputs

\begin{tabular}{|l|c|c|}
\hline Material & Units & Cost (\$/unit) \\
\hline Sinter & tonne & 50 \\
\hline Pellets & tonne & 60 \\
\hline Coke & tonne & 150 \\
\hline $\mathrm{PCl}$ & tonne & 70 \\
\hline Oxygen & $\mathrm{Nm}^{3}$ & 0.03 \\
\hline Nitrogen & $\mathrm{Nm}^{3}$ & 0.02 \\
\hline Air & $\mathrm{Nm}^{3}$ & 0.01 \\
\hline Electricity & $\mathrm{kWh}$ & 0.11 \\
\hline
\end{tabular}

A breakout of the operating cost differences from the base case are provided in Figure 4 below as waterfall diagrams. For each case, the left-most bar represents the operating cost of the base case, with subsequent bars (values shown in $\$ / \mathrm{HM}$ ) representing the incremental step change for coke, blast air, oxygen, power and PCI costs, in that order. Subtracting and adding these bars to the base case cost results in the right-most bar showing the new operating cost for the case presented. 

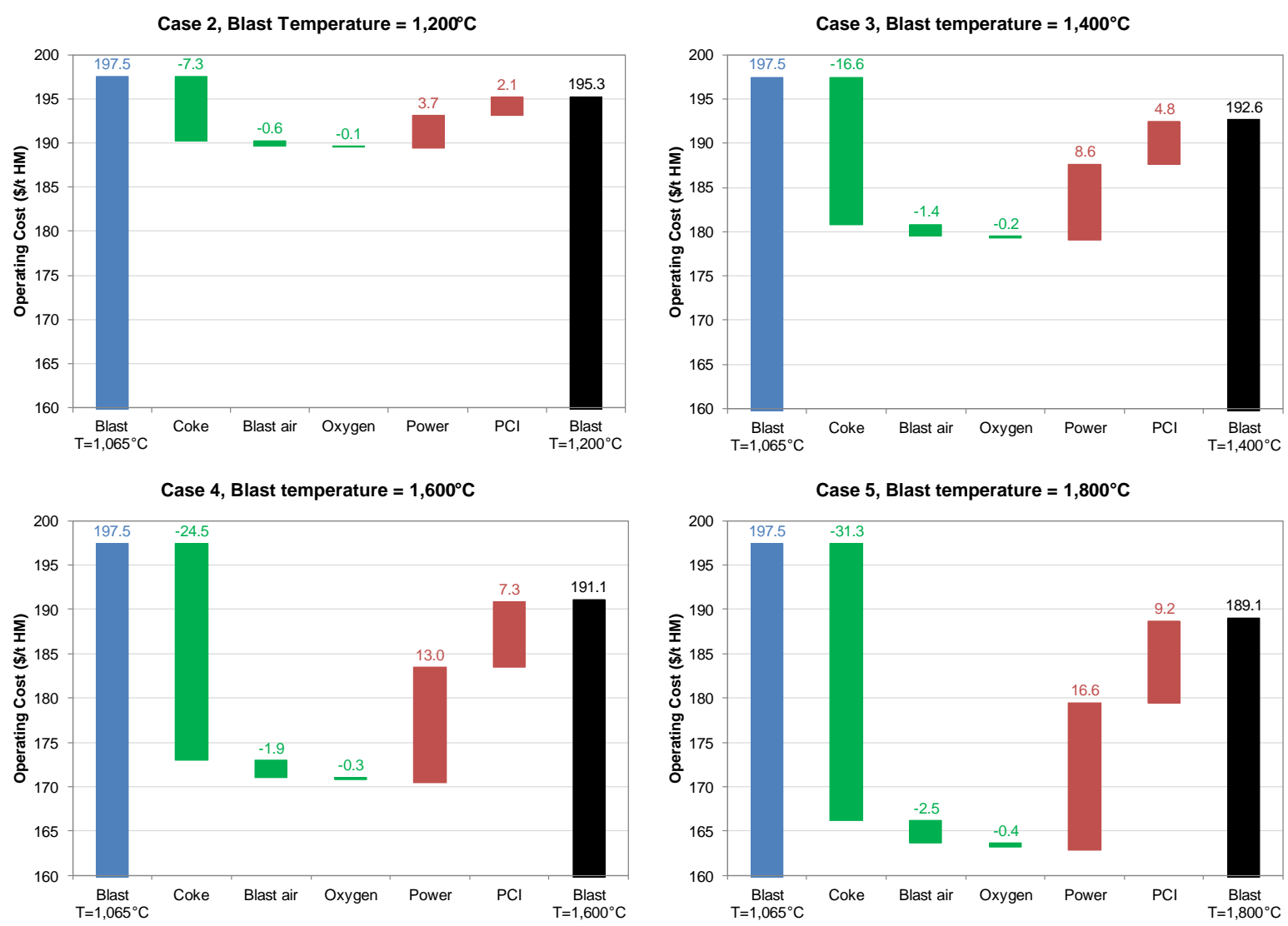

Figure 4. Operating cost differences from Case 1.

The rate of return was based on a 10-year project life, a 1-year implementation period, an installed capital cost of $\$ 2.5$ million for each plasma torch system, and electrical infrastructure upgrade costs at $\$ 100 \mathrm{k}$ per MW for a new substation. A summary of each case is presented in Table 6.

Table 6. Financial analysis summary

\begin{tabular}{|l|c|c|c|c|c|c|}
\hline Parameter & \multirow{2}{*}{ Units } & $\begin{array}{c}\text { Case } \\
\mathbf{1}\end{array}$ & $\begin{array}{c}\text { Case } \\
\mathbf{2}\end{array}$ & $\begin{array}{c}\text { Case } \\
\mathbf{3}\end{array}$ & $\begin{array}{c}\text { Case } \\
\mathbf{4}\end{array}$ & $\begin{array}{c}\text { Case } \\
\mathbf{5}\end{array}$ \\
\hline Blast Temperature & ${ }^{\circ} \mathrm{C}$ & 1,065 & 1,200 & 1,400 & 1,600 & 1,800 \\
\hline Operating Cost & $\$ / \mathrm{t} \mathrm{HM}$ & 197 & 195 & 193 & 191 & 189 \\
\hline Change in operating cost & $\$ / \mathrm{t} \mathrm{HM}$ & - & -2.2 & -4.8 & -6.3 & -8.4 \\
\hline Change in operating cost & million $\$ /$ year & - & -2 & -5 & -6 & -8 \\
\hline Capital cost & million $\$$ & - & 11 & 22 & 33 & 44 \\
\hline Simple payback & years & - & 2.4 & 2.2 & 2.5 & 2.5 \\
\hline Pre-tax IRR & $\%$ & - & 40 & 45 & 38 & 38 \\
\hline
\end{tabular}

Using plasma torches to superheat the blast provides returns on investment in the order of $40 \%$, with a simple payback under 2.5 years for capital costs of $\$ 10-40$ million. The key benefits from increasing the blast temperature are realized in the difference between coke rate savings and increased power requirements.

When planning to implement plasma torches in an existing steel plant, the plant may have available electrical infrastructure that could be used to reduce the investment costs significantly. Additionally, the implementation can be staged, especially if redundant power is available at the plant site. 


\section{CONCLUSION}

Superheating the blast air using plasma torch technology offers an opportunity to reduce coke consumption below today's best practices with oxygen enriched blast and coal injection. The plasma technology can be introduced in a staged manner to allow for the required engineering developments to be completed and optimized. The financial payback is attractive, with payback of about 2.5 years, and this can be achieved for each stage of the technology implementation. Engineering design work is needed to develop the best way to implement the newer plasma torches available from Alter NRG, including an ultra high temperature hot blast system. With a focused development program, these engineering challenges can be overcome.

\section{Acknowledgement}

We are pleased to acknowledge the contributions of our colleagues as we developed this analysis, especially Yakov Gordon and Mitesh Patel.

\section{REFERENCES}

1 Santen, S. et al. Plasma Technology in Metallurgical Processing. Iron and Steel Society 1987, Applications of Plasma Technology in Ironmaking, Ch 9, pp 111-123.

2 Hamblyn, SML. Plasma Technology and its Application to Extractive Metallurgy. Minerals Science Engineering, Vol 9, No 3, July 1977, pp 151-176.

3 Mac Rae, DR. Plasma Arc Process Systems, Reactors, and Applications. Plasma Chemistry and Plasma Processing, Vol 9, No 1, 1989, pp 85S-118S.

4 Keating, E. Thermal Destruction. Applied Combustion, CRC Press, Taylor and Francis Group, $2^{\text {nd }}$ Edition, 2007, Ch. 13, pp 544.

5 Westinghouse Plasma Corporation. Westinghouse Plasma Torches for Foundry \& Ironmaking Applications. Calgary, Canada, 2014. <http://www.alternrg.com>

6 Edstrom, JO. Plasma Technology in Metallurgical Processing. Iron and Steel Society 1987, Economics of Plasma Applications and Comparison with Conventional Alternatives for Iron and Steel Applications, Ch 15, pp 187-195.

7 Fey, MG. et al. Thermal Plasma Systems for Industrial Processes. Proceedings from the Fourth Industrial Energy Technology Conference, Houston, TX, April 4-7, 1982, pp 153-162.

8 Mathieson, JG. et al. Toward an understanding of coal combustion in blast furnace tuyere injection. Fuel, Vol 84, 2005, pp 1229-1237.

9 Rogers, H. et al. The Impact of Coal Petrographic Composition on the Combustion of Pulverised Coals under Simulated Blast Furnace Tuyere Injection Conditions. BlueScope Steel Research, Newcastle, Australia, 2011.

10 General Motors Corporation and Westinghouse Electric Corporation. Plasma Cupola Operations at General Motors Foundry. Paper submitted to the American Foundrymen's Society, Casting Congress, 1998, Atlanta, Georgia. 